\title{
Evaluation of the cardiopulmonary and antinociceptive effects of bupivacaine administered epidurally at the first lumbar vertebra in awake dogs
}

\author{
[Estudo dos efeitos cardiopulmonares e antinociceptivos da administração epidural de \\ bupivacaína à altura da primeira vértebra lombar em cães acordados] \\ P.E.S. Silva, N. Nunes ${ }^{*}$, A.P. Gering, T.C. Prada, A.P.R. Simões, T.F.V. Bompadre, \\ R.V.G. Castro, D.P. Paula
}

Faculdade de Ciências Agrárias e Veterinárias - UNESP - Jaboticabal, SP

\begin{abstract}
The aim of this study was to evaluate the effect of epidural bupivacaine administration at the first lumbar vertebra on cardiopulmonary variables, arterial blood gases and anti-nociception. Sixteen healthy female dogs were randomly assigned into two groups based on bupivacaine dose: G1 group, $1 \mathrm{mg} \mathrm{kg}^{-1}$ or G2 group, $2 \mathrm{mg} \mathrm{kg}^{-1}$, diluted in the same final volume $\left(1 \mathrm{~mL}_{4} \mathrm{~kg}^{-1}\right)$. Cardiopulmonary variables were measured and arterial blood gas was collected (T0), it was repeated 10 minutes after intravenous administration of butorphanol $0.4 \mathrm{mg} \mathrm{kg}^{-1}(\mathrm{~T} 1)$. Anesthesia was induced with intravenous etomidate at $2 \mathrm{mg} \mathrm{kg}^{-1}$ and the epidural catheter was introduced and placed at the first lumbar vertebra. Thirty minutes later, bupivacaine was administered epidurally. Cardiopulmonary measurements and arterial blood gas analysis were recorded at 10 minute intervals (T2 to T6). Evaluation of pre surgical anti-nociception was performed at 5 minute intervals for 30 minutes by clamping the hind limbs, anus, vulva, and tail with the dogs awake. Subsequently, ovariohysterectomy was performed and adequacy of surgical anti-nociception was evaluated at 5 time points. Parametric data were analyzed using the $\mathrm{F}$ test with a $<0.05$ significance. After bupivacaine administration, there were differences between groups just for bicarbonate means $\left(\mathrm{HCO}_{3}{ }^{-}\right)$on T6 ( $\mathrm{P}=0.0198$ ), with $18.7 \pm 1.3$ and $20.4 \pm 0.8$ for $\mathrm{G} 1$ and $\mathrm{G} 2$, respectively. After $\mathrm{T} 1$, before bupivacaine administration, both groups presented a slightly lower $\mathrm{pH}$, base excess (BE), the end-tidal carbon dioxide tension $\left(\mathrm{PECO}_{2}\right)$, and partial pressure of carbon dioxide $\left(\mathrm{PaCO}_{2}\right)$, suggesting mild metabolic acidosis. $\mathrm{G} 2$ showed better antinociceptive effect both before and during surgery. It was possible to perform ovariohysterectomy in $87.5 \%$ of the G2 bitches and $25 \%$ of the G1 bitches. The two doses of bupivacaine evaluated do not cause important alterations in the studied parameters and the dose of $2 \mathrm{mg} \mathrm{kg}^{-1}$ results in a better antinociceptive effect.
\end{abstract}

Keywords: bupivacaine, dog, epidural catheter, regional anesthesia

\section{RESUMO}

O objetivo deste estudo foi avaliar os efeitos da administração epidural de bupivacaína à altura da primeira vértebra lombar sobre variáveis cardiopulmonares, hemogasometria arterial e antinocicepção. Dezesseis cadelas foram separadas aleatoriamente em dois grupos que se diferenciaram pela dose de bupivacaína, $1 \mathrm{mg} / \mathrm{kg}$ (G1) ou $2 \mathrm{mg} / \mathrm{kg}$ (G2), diluídas no mesmo volume final (1 $\mathrm{mL} / 4 \mathrm{~kg}$ ). As variáveis cardiopulmonares e hemogasometria arterial foram coletadas antes (T0) e após 10 minutos da administração intravenosa de $0,4 \mathrm{mg} / \mathrm{kg}$ de butorfanol (T1). A anestesia foi induzida com $2 \mathrm{mg} / \mathrm{kg}$ de etomidato intravenoso para introdução do cateter epidural. Após 30 minutos, a bupivacaína foi administrada e, passados 10 minutos, nova coleta de parâmetros foi feita, sendo repetida a cada 10 minutos (T2 a T6). Após cinco minutos da administração de bupivacaína, iniciou-se a avaliação da antinocicepção pré-cirúrgica, repetida a cada cinco minutos durante 30 minutos. Então, iniciou-se a cirurgia de ovário-histerectomia, na qual se avaliou a antinocicepção transcirúrgica em cinco momentos. Os resultados paramétricos foram analisados pelo software SAS 9.4 (2010), utilizando-se o teste F com

Recebido em 19 de novembro de 2015

Aceito em 29 de março de 2016

*Autor para correspondência (corresponding author)

E-mail: newton@fcav.unesp.br 
significância menor que 0,05. Houve diferença entre as médias dos grupos após administração de bupivacaína apenas para bicarbonato em T6 ( $P=0.0198)$, sendo $18,7 \pm 1,3$ e 20,4 $\pm 0,8$ as médias do G1 e G2, respectivamente. Desde T1, os grupos apresentaram valores de $p H$, excesso de bases, pressão parcial de gás carbônico no sangue arterial e tensão de dióxido de carbono ao final da expiração pouco abaixo do fisiológico, sugerindo acidose metabólica discreta. O G2 apresentou efeito antinociceptivo pré e transcirúrgico superior ao G1. Foi possível realizar a cirurgia em 87,5\% das cadelas do G2 e em $25 \%$ das cadelas do G1. Concluiu-se que as duas doses de bupivacaína avaliadas não acarretam alterações importantes nos parâmetros fisiológicos estudados e a dose de $2 \mathrm{mg} / \mathrm{kg}$ determina melhor efeito antinociceptivo que a dose de $1 \mathrm{mg} / \mathrm{kg}$.

Palavras-chave: anestesia regional, bupivacaína, cão, cateter epidural

\section{INTRODUCTION}

Epidural anesthesia is a regional anesthesia technique routinely used in dogs especially for orthopedic, obstetric and genitourinary surgeries (Massone, 2003). This technique reduces the requirement of other drugs and therefore increases the safety of the procedure (Mcmurphy, 1993). However, surgeries such as ovariohysterectomy in bitches cannot be performed with the lumbosacral epidural technique because the ovarian innervation emerges at the height of the first lumbar vertebra (L1) (Rocha and Massone, 2006).

The placement of an epidural catheter is presented as an effective alternative to block nerve roots located cranially (Passin and Schnath, 2007). This device is an option to extend the time of anesthesia and analgesia by intermittent administration of anesthetic or analgesic solutions (Torske and Dyson, 2000). It also allows administration of fractioned doses of local anesthetic (Imbelloni et al., 2010) promoting lower risk of side effects or toxicity.

Additionally, the use of epidural catheter reduces the risk of injuries, pain caused by repeated injections (Rossi et al., 2010) and the risk of an accidental intravascular or subarachnoid injection (Spiegel et al., 2009).

The most commonly local anesthetics used into the epidural space are lidocaine and bupivacaine. The latency period of bupivacaine is approximately 15 minutes and it acts about 120 to 360 minutes (Torske and Dyson, 2000), promoting comfort during the postoperative period. Considering the clinical importance of bupivacaine and the advantages of the use of epidural catheter, this study aimed to evaluate the cardiopulmonary and arterial blood gas effects of epidural bupivacaine administration at L1. Furthermore, this study also aimed to evaluate if the doses of $1 \mathrm{mg} \mathrm{kg}^{-1}$ or $2 \mathrm{mg} \mathrm{kg}^{-1}$ of epidural bupivacaine were able to promote anesthesia of the ovarian innervation and consequently allow the ovariohysterectomy in dogs.

\section{MATERIAL AND METHODS}

This study was approved by the Animal Ethics and Welfare Committee of the School of Agrarian and Veterinary Sciences of São Paulo State University (UNESP), Brazil (protocol No 019137/14). Sixteen female dogs of mixed breed, aged two to six years old and weighing $14.9 \pm$ $2.8 \mathrm{~kg}$ were selected for this study using a physical examination, $\mathrm{CBC}$, and biochemical profile. Only the dogs considered healthy participated in this study. All owners were aware of the experimental procedure and signed a consent term.

The dogs were totally randomly distributed into the groups that differed only by the epidural bupivacaine dose, $1 \mathrm{mg} \mathrm{kg}^{-1}$ (G1) or $2 \mathrm{mg} \mathrm{kg}^{-1}$ (G2) and there was concern about not using obese dogs as the doses of drugs were calculated by weight.

The animals were food fasted for eight hours and water fasted for two hours. Initially, the animals had the hair clipped from the lumbosacral region, right cephalic vein region, right metatarsal artery region, right neck, and abdomen. Then, a pilocarpine and lidocaine ointment (EMLA, AstraZeneca, Brazil) was applied to the areas to be catheterized. After 10 minutes of ointment application, a catheter (Catheter BD Angiocath 20, Dickinson, Brazil) was inserted into the cephalic vein for the administration of $\mathrm{NaCl} 0.9$ $\%\left(10 \mathrm{~mL} \mathrm{~kg} \mathrm{~h}^{-1}\right)$. The metatarsal artery was also catheterized (Catheter BD Angiocath 22, 
Dickinson, Brazil) for measurement of arterial blood pressure and collecting blood samples.

Fifteen minutes later, baseline (T0) cardiopulmonary variables were measured (Dixtal Model DX-2010 LCD, Brazil): heart rate (HR), systolic (SAP), diastolic (DAP), mean (MAP) arterial pressures, and respiratory rate $\left(f_{R}\right)$. The end-tidal carbon dioxide tension $\left(\mathrm{PECO}_{2}\right)$ was obtained using a sealed mask. Arterial blood samples were collected into a heparinized syringe for measurement of $\mathrm{pH}$, arterial partial pressure of oxygen $\left(\mathrm{PaO}_{2}\right)$, arterial partial pressure of carbon dioxide $\left(\mathrm{PaCO}_{2}\right)$, arterial oxygen saturation $\left(\mathrm{SaO}_{2}\right)$, base excess (BE) and bicarbonate $\left(\mathrm{HCO}_{3}{ }^{-}\right)$(The Omni $\mathrm{C}$. Roche Diagnostics GmbH, Germany). The rectal temperature $\left(\mathrm{RT}^{\circ}\right)$ was measured using a digital thermometer (BD digital thermometer, Dickinson, Brazil).

Buthorphanol $0.4 \mathrm{mg} \mathrm{kg}^{-1}$ (Torbugesic, Ford Dodge, Brazil) was administered intravenously (IV) and additional measurements recorded 10 minutes later (T1). The dogs were anesthetized with etomidate $2 \mathrm{mg} \mathrm{kg}^{-1}$ (Etomidato, Cristália, Brazil) IV. The dogs were positioned in sternal decumbency (sphinx position) and the aseptic preparation of the skin over the lumbosacral area, located by palpation of the dorsal tuberosities of the ilium and dorsal crest of the seventh lumbar vertebra (L7) was performed.

A Weiss type Tuohy needle (BD Tuohy Needle 17GX3,5, Becton Dickinson, Brazil) was inserted into the lumbosacral region to the epidural space. An epidural catheter (Epidural catheter 16G, Portex, Brazil) was introduced throughout the needle and positioned at the height of the first lumbar vertebra previously identified by counting the spinous processes and the measurement of the catheter. It was standardized to cut the remaining catheter keeping one centimeter out of the skin for fixation.

After insertion of the catheter, the animals were transported to the diagnostic imaging sector of the veterinary hospital, positioned in right lateral decumbency, and a spine radiography was held for the measurement in centimeters of the length from L1 to L7. The purpose of this measure was to confirm the correct placement of the epidural catheter at the end of the experiment.
After the spine radiography, SAP, $f_{R}$, and $H R$, which were considered pre surgical values, were also collected. This information was used in the evaluation of sensory block during de surgery.

A standard 30 minute interval between the application of etomidate and bupivacaine (Bupivacaine Hydrochloride $0.75 \%$, Cristália, Brazil) was set. This administration was made with the animals in sphinx position. The interval was standardized to ensure that the patients were awake, therefore not disturbing the pre surgical anti-nociception evaluation. The dose of epidural bupivacaine varied according to the group, $1 \mathrm{mg}$ $\mathrm{kg}^{-1}$ (G1) and $2 \mathrm{mg} \mathrm{kg}^{-1}$ (G2), with the final volume of $1 \mathrm{~mL}^{2} \mathrm{~kg}^{-1}$ in both groups. The bupivacaine concentration used was $0.75 \%$, so the dose of $2 \mathrm{mg} \mathrm{kg}^{-1}$ was equal to $1 \mathrm{~mL} 4 \mathrm{~kg}^{-1}$. Thereby, the bupivacaine of G1 was diluted with $\mathrm{NaCl} \quad 0.9 \%$ until the final volume and administered at a concentration of $0.37 \%$.

Ten minutes after bupivacaine administration, a new measurement of cardiopulmonary parameters and arterial blood gas was performed (T3) and this evaluation was repeated at 10 minute intervals until T6 which was the moment of the ligature of the left ovary.

Independently and simultaneously, five minutes after the bupivacaine administration, the pre surgical anti-nociception evaluation was initiated and repeated at five minute intervals until 30 minutes of evaluation (S1 to S6) with the animals awake and in sphinx position. For this evaluation, the tail, anus, vulva and webbing between second and third phalanges of both hind limbs were clamped using a Kocher clamp, it was always performed by the same researcher who was not aware of the bupivacaine dose utilized.

Scores have been assigned to the animal's response to the stimulus, being 0 (absent), 1 (decreased) and 2 (normal).

At the end, the dogs were positioned in dorsal decumbency for the ovariohysterectomy surgery. An anti-nociception evaluation was performed as stated in Tab. 1. The five time points of the procedure were: clamping of the umbilical scar (P1); ligature of the left ovary (P2), ligature of the right ovary (P3), ligature of the uterine stump (P4) and start of the skin suture (P5). 
Table 1. Qualitative analysis of the effectiveness of anesthetic block during the surgical period through scores given by an observer, according to the possible changes that could be found (Canôa, 2009)

\begin{tabular}{lll}
\hline Parameters & Criterion & Scores \\
\hline \multirow{2}{*}{ Heart rate } & $\leq 10 \%$ greater than the pre surgical value & 0 \\
Respiratory rate & 11 a $30 \%$ greater than the pre surgical value & 1 \\
Systolic blood pressure & 31 a $49 \%$ greater than the pre surgical value & 2 \\
& $50 \%$ greater than the pre surgical value & 3 \\
\hline \multirow{2}{*}{ Salivation } & Normal & 0 \\
& Above normal & 1 \\
\hline \multirow{2}{*}{ Pupillarydiameter } & Normal & 0 \\
& Mydriasis & 1 \\
\multirow{2}{*}{ Vocalization } & No vocalization & 0 \\
& Vocalization present and controlled without medication & 1 \\
\hline \multirow{3}{*}{ Agitation } & Uncontrolled vocalization & 2 \\
& Asleep or calm & 0 \\
& Little agitation & 1 \\
& Moderate agitation & 2 \\
\hline
\end{tabular}

The sum of the scores for each variable was grouped: between $0-5$ meaning good antinociceptive effect, between 6-7 a discreet antinocipetive effect and above 7 insufficient antinociceptive effect. All animals with the sum of scores above 5 were induced to general anesthesia with propofol (Propovan, Cristália, Brazil), intubated with Magill tube properly sized and maintained in inhalation anesthesia with isoflurane (Isoforine, Cristália, Brazil) diluted in $60 \%$ of oxygen and they did not participate in the subsequent evaluations.

All surgeries were performed by the same surgeon and auxiliary and lasted on average 30 minutes. After the surgery the epidural catheters were removed, measured in centimeters and the measurements were compared to those obtained in the radiographs. When the measurements showed discrepancy, the animal data was discarded and the whole procedure was repeated with another animal.

Before being returned to owners, the bitches received intramuscular (IM) tramadol $4 \mathrm{mg} \mathrm{kg}^{-1}$ (Tramadol hydrochloride, Hipolabor, Brazil), subcutaneous (SC) meloxicam (Meloxicam, Eurofarma, Brazil) $0.1 \mathrm{mg} \mathrm{kg}^{-1}$ and pentabiotic (Veterinary pentabiotic, Fort Dodge, Brazil) 30000 UI kg ${ }^{-1}$ IM.

The data related to cardiopulmonary parameters and arterial blood gas, the averages of weight and spine length (L1-L7) were analyzed using
Statistical... (2010) and the F test, considering $\mathrm{P}<0.05$ as significant. These parameters were also analyzed using orthogonal contrasts to determine linear or quadratic behavior of the averages over time. The results for the evaluation of sensory block and nociception were presented as percentage to support the conclusion.

\section{RESULTS AND DISCUSSION}

The butorfanol was chosen for premedication due to its good sedative effect and minimal changes in the cardiovascular and respiratory systems (Jacobson et al.,1994; Quandt et al., 1994; Scrivani et al., 1998). The etomidate was chosen for anesthetic owing to its short-lasting effect (Ko et al., 1994) and low or not present cardiovascular or respiratory changes when it is used as a single dose (Buljubasic et al., 1996). The dose of $2 \mathrm{mg} \mathrm{kg}^{-1}$ was adequate for the insertion of the epidural catheter and it was decided to $\mathrm{x}$-ray the patients after anesthesia because the remaining effect of the drug allowed a better position for the exam.

Regarding the results found for the cardiovascular variables, specifically the HR, the assessment contrasts showed that both groups have linear trends, with their average tending to decline over time (Tab. 2). This decrease, observed after intravenous administration of $0.4 \mathrm{mg} \mathrm{kg}^{-1}$ butorphanol, complies with the studies conducted by Trim (1983), Greene et al. (1990) and Quandt et al. (1994). In these studies, 
a decrease in this parameter in dogs that received $0.4 \mathrm{mg} \mathrm{kg} \mathrm{kg}^{-1}$ butorphanol intravenously was observed, and this finding was related to the vagal activity promoted by the opioid.

There were different HR averages between the groups only at the initial moment $(\mathrm{P}=0.0019)$. Since no drug was administered, it suggests that only individual variation might have occurred. In G1 it was observed that the average of HR in T6 was greater than in $\mathrm{T} 5$, although no statistical difference was verified $(\mathrm{P}=0.2690)$. One possible explanation for this increase is that the T6 bitches were in the ligature of left ovarian pedicle and $75 \%$ of them showed discreet or insufficient anesthetic block, demonstrating increased HR due to painful stimulus. The same increase was observed for SAP, DAP, and MAP (Tab. 2).

With regard to SAP, DAP, and MAP, there was a reduction in the average values of these parameters after butorphanol administration, between $\mathrm{T} 1$ and $\mathrm{T} 2$, with no difference between the groups. According to Tyner et al. (1989), decrease in blood pressure after administration of this opioid may be attributed to the reduction in total peripheral resistance promoted by the drug. This fact was also reported by Santos et al. (2004).

Despite the fact that average decreased over time after the administration of the opioid, the HR, SAP, DAP, and MAP values were within or very close to the considered physiological range for dogs, not compromising the cardiovascular stability.

Regarding the other parameters, the interpretation of the data for respiratory parameters $\left(\mathrm{f}_{\mathrm{R}}, \mathrm{PECO}_{2}\right)$ and hemogasometry $(\mathrm{pH}$, $\mathrm{BE}, \mathrm{PaCO}_{2}$ ) of both groups showed that the dogs had a mild metabolic acidosis (Tab. 2). Such acidosis stimulated the respiratory center taking to an increasing of $\mathrm{f}_{\mathrm{R}}$ and a reduction of $\mathrm{PaCO}_{2}$, $\mathrm{PECO}_{2}$ and $\mathrm{BE}$. Despite the significant differences between groups for $\mathrm{HCO}_{3}{ }^{-}$ $(\mathrm{P}=0.0198)$, this parameter did not show major changes.

A possible explanation for the metabolic acidosis is that the pre surgical fasting accompanied by the sympathetic nervous system activation caused by stress resulted in increased production and release of vasopressin as well as antidiuretic hormone whose function is to retain sodium and water in the renal tubules (Houpt, 2006). This mechanism generates acids decreased elimination via kidneys and may justify the slight metabolic acidosis found in dogs in both groups. These data corroborate Gering (2012).

The $\mathrm{SaO}_{2}$ and $\mathrm{PaO}_{2}$ were also measured in arterial blood gas and it was possible to observe that the protocol used did not affect the oxygenation of patients, regardless of the analyzed experimental group (Tab. 2).

The evaluation of pre surgical anti-nociception was assessed during 30 minutes, because previous reports in literature showed that bupivacaine latency time is approximately 15 to 20 minutes (Torske and Dyson, 2000; Klaumann et al., 2013). The results are in accordance with the authors, because the percentage of animals in each score was changed over the time, but stabilized between 20-25 minutes from the application of bupivacaine.

All the variables showed differences in the results, being the dose of $2 \mathrm{mg} \mathrm{kg}^{-1}$ more effective than the dose of $1 \mathrm{mg} \mathrm{kg}^{-1}$ under these experimental conditions (Tab. 3 ).

The tail showed the higher percentages of absent sensitivity (score 0) in both groups in relation to other points of evaluation. The caudal nerve is responsible for tail innervation; this nerve emerges from the lumbosacral junction in dogs and it is not a nerve of large diameter (Parent, 2010). The same volume was administered in G1 and $\mathrm{G} 2$, however, G1 was diluted until the final volume of $1 \mathrm{~mL} 4 \mathrm{~kg}^{-1}$. Thus, it seems that the anesthetic applied in G1 was not in sufficient concentration to block the nerve in $100 \%$ of the dogs.

The pudendal nerve is responsible for innervating the anus, vulva, urethra and perineal skin. In the dog, this nerve emerges from the first, second and third sacral vertebras (Parent, 2010). Thereby this justifies the fact that each group presents distributions of scores equal to the vulva and anus. It is noteworthy that in both groups diffusion to the sacral vertebrae was obtained. Although G2 presented better results, it was not enough to block the nerve in $100 \%$ of the bitches. A possible explanation for this fact is 
that the fibers from the lumbosacral plexus emerge at the fourth and fifth lumbar vertebras, therefore the spinal cord becomes thicker in this region (Parent, 2010). Thus, this physiological reduction of the epidural space may have hampered the spread of anesthetic to the sacral vertebras in some patients.

Table 2. Averages, standard deviation (SEM) and orthogonal contrasts of heart rate (HR), respiratory rate $\left(f_{R}\right)$, systolic blood pressure (SAP), diastolic blood pressure (DAP), mean arterial pressure (MAP), endtidal carbon dioxide tension $\left(\mathrm{PECO}_{2}\right)$, partial pressure of carbon dioxide $\left(\mathrm{PaCO}_{2}\right)$, partial pressure of oxygen $\left(\mathrm{PaO}_{2}\right)$, arterial oxygen saturation $\left(\mathrm{SaO}_{2}\right)$, base excess $(\mathrm{BE})$, bicarbonate $\left(\mathrm{HCO}_{3}{ }^{-}\right)$, and $\mathrm{pH}$. in dogs $(\mathrm{n}=16)$ undergoing elective ovariohysterectomy and epidural anesthesia with bupivacaine in doses of $1 \mathrm{mg} \mathrm{kg}^{-1}$ (G1) and $2 \mathrm{mg} \mathrm{kg}^{-1}(\mathrm{G} 2)$

\begin{tabular}{|c|c|c|c|c|c|c|c|c|c|c|c|}
\hline \multirow[t]{2}{*}{ Variable } & \multirow[t]{2}{*}{ Group } & \multicolumn{7}{|c|}{ Time of collection } & \multirow[t]{2}{*}{ SEM } & \multirow[t]{2}{*}{$\begin{array}{l}\text { Linear } \\
\text { contrast }\end{array}$} & \multirow[t]{2}{*}{$\begin{array}{l}\text { Quadratic } \\
\text { contrast }\end{array}$} \\
\hline & & T0 & T1 & T2 & T3 & $\mathrm{T} 4$ & T5 & T6 & & & \\
\hline \multirow{2}{*}{$\begin{array}{l}\mathrm{HR} \\
(\mathrm{bpm})\end{array}$} & G1 & $88.5 \mathrm{Aa}$ & $88.5 \mathrm{a}$ & $70 \mathrm{~b}$ & $76 \mathrm{ab}$ & $72 b$ & $68.7 \mathrm{~b}$ & 76.6ab & 6.4 & 0.005 & 0.09 \\
\hline & $\mathrm{G} 2$ & $115.7 \mathrm{Ba}$ & $91.2 \mathrm{~b}$ & $79.5 \mathrm{bc}$ & $77 \mathrm{bc}$ & $75.7 \mathrm{c}$ & $75 \mathrm{c}$ & $73.7 \mathrm{c}$ & 8.2 & $<.0001$ & 0.32 \\
\hline \multirow{2}{*}{$\begin{array}{l}\text { SAP } \\
(\mathrm{mmHg})\end{array}$} & G1 & $118.1 \mathrm{ab}$ & $118.8 \mathrm{ab}$ & $114.3 \mathrm{a}$ & $115.1 \mathrm{a}$ & $120.8 \mathrm{ab}$ & $130.2 b$ & $122.7 \mathrm{ab}$ & 6.4 & 0.58 & 0.65 \\
\hline & $\mathrm{G} 2$ & 119.8 & 111 & 105.5 & 112.1 & 103.6 & 119.1 & 112.7 & 6.6 & 0.03 & 0.76 \\
\hline \multirow{2}{*}{$\begin{array}{l}\begin{array}{l}\text { DAP } \\
(\mathrm{mmHg})\end{array} \\
\end{array}$} & G1 & 85.2 & 79.5 & 74.2 & 79 & 81.1 & 88.6 & 84.6 & 6.7 & 0.13 & 0.96 \\
\hline & G2 & $90.8 \mathrm{a}$ & $76.6 \mathrm{~b}$ & $75 b$ & $68.8 \mathrm{~b}$ & $69.1 \mathrm{~b}$ & $79 \mathrm{ab}$ & $71 \mathrm{~b}$ & 5.2 & 0.01 & 0.24 \\
\hline \multirow{2}{*}{$\begin{array}{l}\text { MAP } \\
(\mathrm{mmHg})\end{array}$} & G1 & 102.8 & 100.1 & 96.1 & 97.3 & 99.6 & 109.5 & 104.6 & 6.66 & 0.31 & 0.91 \\
\hline & $\mathrm{G} 2$ & $105.7 \mathrm{a}$ & $95.5 \mathrm{bd}$ & $87.1 \mathrm{bc}$ & $87.2 \mathrm{bc}$ & $85.7 \mathrm{c}$ & $99.5 \mathrm{ad}$ & $91.7 \mathrm{bcd}$ & 5.09 & 0.0001 & 0.80 \\
\hline \multirow{2}{*}{$\begin{array}{l}f_{R} \\
(\mathrm{mpm})\end{array}$} & G1 & 20.2 & 24.5 & 23 & 21.6 & 21.5 & 20.6 & 23.6 & 4.59 & 0.49 & 0.40 \\
\hline & $\mathrm{G} 2$ & $26.6 \mathrm{a}$ & $20.2 \mathrm{~b}$ & $17.3 \mathrm{~b}$ & $17 \mathrm{~b}$ & $16.1 \mathrm{~b}$ & $14.2 \mathrm{~b}$ & $16.1 \mathrm{~b}$ & 2.31 & 0.004 & 0.51 \\
\hline \multirow{2}{*}{$\begin{array}{l}\begin{array}{l}\mathrm{PECO}_{2} \\
(\mathrm{mmHg})\end{array} \\
\end{array}$} & G1 & $33.7 \mathrm{ab}$ & $34 \mathrm{ab}$ & $31 \mathrm{ab}$ & $34.8 \mathrm{a}$ & $31.6 \mathrm{ab}$ & $33.3 \mathrm{ab}$ & $30.1 \mathrm{~b}$ & 2.07 & 0.17 & 0.35 \\
\hline & $\mathrm{G} 2$ & 30.5 & 35.3 & 30.2 & 31.6 & 33.8 & 34.7 & 32.6 & 2.08 & 0.04 & 0.22 \\
\hline \multirow{2}{*}{$\begin{array}{l}\mathrm{PaO}_{2} \\
(\mathrm{mmHg})\end{array}$} & G1 & 100.4Aab & $101.5 \mathrm{ab}$ & $106.8 \mathrm{a}$ & $98.1 \mathrm{~b}$ & $104 a b$ & $102.3 \mathrm{ab}$ & $106.9 \mathrm{a}$ & 2.99 & 0.05 & 0.46 \\
\hline & $\mathrm{G} 2$ & $109.8 \mathrm{~B}$ & 96.7 & 102.6 & 103.9 & 106.7 & 99.5 & 101.5 & 4.06 & 0.15 & 0.03 \\
\hline \multirow{2}{*}{$\begin{array}{l}\mathrm{PaCO}_{2} \\
(\mathrm{mmHg})\end{array}$} & G1 & $33.9 \mathrm{a}$ & $36.2 \mathrm{ab}$ & $35.6 \mathrm{ab}$ & $38.1 \mathrm{~b}$ & $36.3 \mathrm{ab}$ & $35.9 \mathrm{a}$ & $34.1 \mathrm{a}$ & 1.17 & 0.19 & 0.18 \\
\hline & G2 & 34 & 38.4 & 36.8 & 36.8 & 36.5 & 37 & 36.9 & 1.14 & 0.02 & 0.008 \\
\hline \multirow{2}{*}{$\begin{array}{l}\mathrm{SaO}_{2} \\
(\%)\end{array}$} & G1 & $96.4 \mathrm{ab}$ & $96.5 \mathrm{Aabc}$ & $97.2 \mathrm{ac}$ & $96.1 \mathrm{~b}$ & 97.1ac & $96.9 \mathrm{abc}$ & $97.3 \mathrm{c}$ & 0.39 & 0.06 & 0.44 \\
\hline & $\mathrm{G} 2$ & $97.2 \mathrm{a}$ & $95.4 \mathrm{Bb}$ & $96.7 \mathrm{a}$ & $97 \mathrm{a}$ & $97.3 \mathrm{a}$ & $96.8 \mathrm{a}$ & $97.2 \mathrm{a}$ & 0.36 & 0.32 & 0.001 \\
\hline \multirow{2}{*}{$\mathrm{pH}$} & G1 & $7.34 \mathrm{ab}$ & $7.33 \mathrm{a}$ & $7.34 \mathrm{ab}$ & $7.33 \mathrm{ab}$ & 7.35abc & $7.35 b c$ & $7.36 \mathrm{c}$ & 0.01 & 0.51 & 0.26 \\
\hline & $\mathrm{G} 2$ & $7.36 \mathrm{ac}$ & $7.33 b$ & $7.32 \mathrm{~b}$ & $7.34 \mathrm{bd}$ & $7.35 \mathrm{~cd}$ & 7.35acd & $7.36 \mathrm{ac}$ & 0.008 & $<.0001$ & 0.07 \\
\hline \multirow{2}{*}{$\begin{array}{l}\mathrm{BE} \\
(\mathrm{mmol} / \mathrm{L})\end{array}$} & G1 & $-5.92 \mathrm{a}$ & $-5.97 a$ & $-5.97 \mathrm{a}$ & $-5.08 b$ & $-5.20 b$ & $-4.83 b$ & $-5.38 \mathrm{ab}$ & 0.63 & 0.87 & 0.92 \\
\hline & G2 & $-5.06 \mathrm{ac}$ & $-5.25 \mathrm{a}$ & $-6.35 b$ & $-5.30 \mathrm{a}$ & $-5.36 \mathrm{a}$ & $-4.78 \mathrm{ac}$ & $-4.33 c$ & 0.57 & 0.002 & 0.19 \\
\hline \multirow{2}{*}{$\begin{array}{l}\mathrm{HCO}_{3}^{-} \\
(\mathrm{mmol} / \mathrm{L})\end{array}$} & G1 & 18.1a & $18.6 \mathrm{a}$ & $18.7 \mathrm{a}$ & $19.9 \mathrm{~b}$ & $19.5 \mathrm{bc}$ & $19.7 b$ & 18.7Aac & 0.63 & 0.17 & 0.49 \\
\hline & G2 & $18.6 \mathrm{a}$ & $19.4 \mathrm{ab}$ & $18.6 \mathrm{a}$ & $19.4 \mathrm{ab}$ & $19.5 \mathrm{ab}$ & $20.1 \mathrm{~b}$ & $20.4 \mathrm{Bb}$ & 0.49 & 1.00 & 0.05 \\
\hline
\end{tabular}

Means followed by different small letters in the same line are significantly different $(\mathrm{P}<0.05)$.

Means followed by different capital letters in the same column referring to the same variable are significantly different $(\mathrm{P}<0.05)$.

Table 3. Percentage of dogs $(n=16)$ that underwent epidural bupivacaine administered at the first lumbar vertebra at $1 \mathrm{mg} \mathrm{kg}^{-1}(\mathrm{G} 1)$ or $2 \mathrm{mg} \mathrm{kg}^{-1}$ (G2), with framed scores 0 (absent), 1 (decreased) and 2 (normal), answering the stimulus given for assessment of sensory block after 30 minutes of the bupivacaine administration (S6)

\begin{tabular}{lllll}
\hline Variable & Group & Scores & & \\
\hline \multirow{2}{*}{ Tail } & & 0 & 1 & 2 \\
\hline \multirow{2}{*}{ Anus } & G1 & $75 \%$ & $12.5 \%$ & $12.5 \%$ \\
& G2 & $100 \%$ & 0 & 0 \\
\hline \multirow{2}{*}{ Vulva } & G1 & $50 \%$ & $25 \%$ & $25 \%$ \\
& G2 & $87.5 \%$ & $12.5 \%$ & 0 \\
\hline \multirow{2}{*}{ Right hind limb } & G1 & $50 \%$ & $25 \%$ & $25 \%$ \\
& $\mathrm{G} 2$ & $87.5 \%$ & $12.5 \%$ & 0 \\
\hline \multirow{2}{*}{ Left hind limb } & $\mathrm{G} 1$ & $50 \%$ & $12.5 \%$ & $37.5 \%$ \\
& $\mathrm{G} 2$ & $100 \%$ & 0 & 0 \\
\hline
\end{tabular}


The sensitivity of the hind limbs was also evaluated and they are innervated mainly by sciatic and femoral nerves. The femoral nerve originates from the fourth, fifth and sixth lumbar vertebras (Parent, 2010). Rocha and Massone (2006) also reported the emergence of the femoral nerve in the sixth lumbar vertebra. The sciatic nerve is the largest nerve in the body and emerges from the roots of the sixth lumbar vertebra, seventh lumbar vertebra, first sacral vertebra and second sacral vertebra (Parent, 2010). Similarly, the dose used in G1 was not sufficient to block $100 \%$ of the two nerves of the animals. It suggested that the difference in the percentage of animals within each score when comparing the right hind limb and left hind limb in G1 is due to uneven dispersion of the anesthetic.

Tab. 1 was adapted from the Canôa (2009) study, which evaluated the surgical analgesia during ovariohysterectomy in bitches. This table was also used by Gering with the same proposal. In the present study it was used for assessing the effectiveness of anti-nociception and applied at 5 surgery time points.

The $\mathrm{P} 2$ period, in which there was the clamping and ligature of the left pedicle, $62.5 \%$ of the bitches from the G1 showed discreet sensory block while $12.5 \%$ showed insufficient sensory block, nevertheless they were all induced to general anesthesia. The same results were observed in G2, with $12.5 \%$ of the bitches showing discreet sensory block. The remaining dogs of both groups, $25 \%$ of G1 and $87.5 \%$ of G2, presented a good sensory block score during all other periods of the surgical assessment. It is important to emphasize that the left ovarian pedicle was clamped before the right only due to surgical standardization reasons.

Guinard et al. (1992) mentions that the placement of the epidural catheter in the dermatomes which will suffer surgical injury is critical to ensure analgesia. In this study, the catheter positioned in the first lumbar vertebra was able to anesthetize the dermatome in which the surgical incision has been made, since the animals of both groups allowed the skin and musculature incision.

It was expected that the position of the catheter in this vertebra allow the realization of ovariohysterectomy because Rocha and Massone (2006) showed that from L1 emerges the uteroovarian plexus, responsible for supplying the ovaries, oviduct and uterus. However, the results showed that a dose of $1 \mathrm{mg} \mathrm{kg}^{-1}$ bupivacaine $0.75 \%$ diluted until the final volume $1 \mathrm{~mL} / 4 \mathrm{~kg}$ was not sufficient to block this plexus in $75 \%$ of patients.

The ovariohysterectomy was chosen for standardization of surgical stimulus and adaptation to animal welfare. Nevertheless, this study has as its ultimate goal the clinical applicability in debilitated animals or who have comorbidities and requiring laparotomy. The epidural catheter is shown as an alternative to increase the safety of the procedure because it can be associated with other techniques, reducing the required doses of drugs (Mcmurphy, 1993). The use of bupivacaine under these experimental conditions did not cause significant changes in physiological parameters, being a safe option for use in dogs.

\section{CONCLUSION}

The doses of $1 \mathrm{mg} \mathrm{kg}^{-1}$ and $2 \mathrm{mg} \mathrm{kg}^{-1}$ of epidural bupivacaine administered at the first lumbar vertebra did not cause significant changes in cardiopulmonary and arterial blood gas parameters, being a safe option to be used in dogs. The dose of $2 \mathrm{mg} \mathrm{kg}^{-1}$ results in a better sensory block compared to dose of $1 \mathrm{mg} \mathrm{kg}^{-1}$ allowing ovariohisterectomy in bitches.

\section{ACKNOWLEDGEMENTS}

The authors would like to thank CAPES for their financial support.

\section{REFERENCES}

BULJUBASIC, N.; MARIJIC, J.; BERCZI, V. et al. Differential effects of etomidate, propofol, and midazolam on calcium and potassium channel currents in canine myocardial cells. Anesthesiology, v.85, p.1092-1099, 1996.

CANÔA, J.T.B. Analgesia peridural com ropivacaína associada ao midazolam em cadelas submetidas à ovariohisterectomia. 2009. 46f. Dissertação (Mestrado em Ciência Animal) - Faculdade de Medicina Veterinária de Araçatuba, Universidade Estadual Paulista, Araçatuba, SP. 
GERING, A.P. Avaliação de duas doses de lidocaína, administradas à altura da primeira vértebra lombar, sobre a analgesia trans-cirurgica e parâmetros cardiorrespiratórios em cadelas submetidas à ovariohisterectomia. 2012. 94f. Dissertação (Mestrado em Ciência Veterinária) - Universidade Estadual Paulista Júlio de Mesquita Filho, Jaboticabal, SP.

GREENE, S.A.; HARTSFIELD, S.M.; TYNER, C.L. Cardiovascular effects of butorphanol in halothane anesthetized dogs. Am. J. Vet. Res., v.51, p.1276-1279, 1990.

GUINARD, J.P.; MAVROCORDATOS, P.; CHIOLERO, R.; CARPENTER, R.L. A randomized comparison of intravenous versus lumbar and thoracic epidural fentanyl for analgesia after thoracotomy. Anesthesiology, v.77, p.1108-1115, 1992.

IMBELLONI, L.E.; GASPARANI NETO, S.; GANEM, E.M. Raquianestesia contínua com altas doses de anestésicos locais. Rev. Bras. Anestesiol., v. 60 , p.537-543, 2010.

JACOBSON, J.D., MCGRATH, C.J., SMITH, E.P. Cardiorespiratory effects of induction and maintenance of anesthesia with ketamine-midazolam combination, with and without prior administration of butorphanol or oxymorphone. Am. J. Vet. Res., v.55, p.543-550, 1994.

KLAUMANN, P.R.; KLOSS FILHO, J.C.; NAGASHIMA, J.K. Anestésicos locais. In: KLAUMANN, P.R.; OTERO, P.E. Anestesia locorregional em pequenos animais. São Paulo: Roca, 2013. p.23-41.

KO, J.C.; THURMON, J.C.; BENSON, G.J. et al. Hemodynamic and anesthetic effects of etomidate infusion in medetomidine-premedicated dogs. Am. J. Vet. Res., v.55, p.842-846, 1994.

MASSONE, F. Anestesia local. In: Anestesiologia veterinária: farmacologia e técnicas. 4.ed. Rio de Janeiro: Guanabara Koogan, 2003. p.3348.

MCMURPHY, R.M. Postoperative epidural analgesia. Vet. Clin. N. Am. Small Anim. Pract., v.23, p.703-716, 1993
PARENT, J. Clinical approach and lesion localization in patient with spinal disease. Vet. Clin. N. Am. Small Anim. Pract., v.40, p.733-753, 2010.

PASSIN, S.; SCHNATH, F. Cuidados de enfermagem na analgesia por cateter peridural. Rev. HCPA, v.27, p.69-73, 2007.

QUANDT, J.E.; RAFFE, M.R.; ROBINSON, E.P. Butorphanol does not reduce the minimum alveolar concentration of halothane in dogs. Vet. Surg., v.23, p.156-159, 1994.

ROCHA, L.M.S.; MASSONE, F. Estudo anatomoanestesiológico do segmento lombar (L1 a L6) em cães. Braz. J. Vet. Res. Anim. Sci., v.43, p.167-177, 2006 .

SANTOS, P.S.P.; NUNES, N.; SOUZA, A.P. et al. Efeitos eletrocardiográficos do butorfanol em cães anestesiados pelo desfluorano. Ciênc. Rural, v.34, p.1105-1111, 2004.

STATISTICAL Analysis System. Version 9.4. Cary: SAS Institute, 2010

SCRIVANI, P.V.; BERDNARSKI, R.M.; MYER, C.W. Effects of acepromazine and butorphanol on positive-contrast upper gastrointestinal trast examination in dogs. Am. J. Vet. Res., v.59, p.12271233,1998

SPIEGEL, J.E.; VASUDEVAN, A.; LI, Y.; HESS, P.E. A randomized prospective study comparing two flexible epidural catheters for labour analgesia. $\mathrm{Br}$. J. Anaesth., v.103, p.400-405, 2009.

TORSKE, K.E.; DYSON, D.H. Epidural analgesia and anesthesia. Vet. Clin. N. Am. Small Anim. Pract., v.30, p.859-874, 2000.

TRIM, C.M. Cardiopulmonary effects of butorphanol tartrate in dogs. Am. J. Vet. Res., v.44, p.329-331, 1983.

TYNER, C.L.; GREENE, S.A.; HARTSFIELD, S.M. Cardiovascular effects of butorphanol administration in isoflurane $-\mathrm{O}_{2}$ anesthetized healthy dogs. Am. J. Vet. Res., v.50, p.1340-1342, 1989. 